\title{
Bioreactor-based bioremediation of hydrocarbon-polluted Niger Delta marine sediment, Nigeria
}

\author{
Chioma Blaise Chikere • Blaise Ositadinma Chikere • \\ Gideon Chijioke Okpokwasili
}

Received: 20 May 2011/Accepted: 3 October 2011/Published online: 21 October 2011

(c) The Author(s) 2011. This article is published with open access at Springerlink.com

\begin{abstract}
Crude oil-polluted marine sediment from Bonny River loading jetty Port Harcourt, Nigeria was treated in seven 2.51 stirred-tank bioreactors designated BNPK, BNK5, BPD, $\mathrm{BNO}_{3}, \mathrm{BUNa}, \mathrm{BAUT}$, and BUK over a 56-day period. Five bioreactors were biostimulated with either $\mathrm{K}_{2} \mathrm{HPO}_{4}$, $\mathrm{NH}_{4} \mathrm{NO}_{3},\left(\mathrm{NH}_{4}\right)_{2} \mathrm{SO}_{4}, \mathrm{NPK}$, urea or poultry droppings while unamended (BUNa) and heat-killed (BAUT) treatments were controls. For each bioreactor, $1 \mathrm{~kg}$ (wet weight) sediment amended with 11 seawater were spiked with $20 \mathrm{ml}$ and $20 \mathrm{mg}$ of crude oil and anthracene which gave a total petroleum hydrocarbons (TPH) range of 106.4-116 ppm on day 0 . Polycyclic aromatic hydrocarbons (PAH) in all spiked sediment slurry ranged from 96.6 to $104.4 \mathrm{ppm}$. TPH in each treatment was $\leq 14.9 \mathrm{ppm}$ while $\mathrm{PAH}$ was $\leq 6.8 \mathrm{ppm}$ by day 56. Treatment $\mathrm{BNO}_{3}$ recorded highest heterotrophic bacterial count $\left(9.8 \times 10^{8} \mathrm{cfu} / \mathrm{g}\right)$ and hydrocarbon utilizers $(1.15 \times$ $\left.10^{8} \mathrm{cfu} / \mathrm{g}\right)$. By day 56 , the percentages of biodegradation of PAHs, as measured with GC-FID were BNK5 (97.93\%), BNPK (98.38\%), BUK (98.82\%), BUNa (98.13\%), BAUT (93.08\%), BPD (98.92\%), and $\mathrm{BNO}_{3}(98.02 \%)$. BPD gave the highest degradation rate for $\mathrm{PAH}$. TPH degradation rates were as follows: BNK5 (94.50\%), BNPK (94.77\%), BUK (94.10\%), BUNa (94.77\%), BAUT (75.04\%), BPD (95.35\%), $\mathrm{BNO}_{3}(95.54 \%)$. Fifty-six hydrocarbon utilizing bacterial isolates obtained were Micrococcus spp. 5 (9.62\%),
\end{abstract}

C. B. Chikere $(\bowtie) \cdot$ G. C. Okpokwasili

Department of Microbiology, University of Port-Harcourt,

P.M.B. 5323, East-West Road, Choba, Port Harcourt,

Rivers State, Nigeria

e-mail: ujuazed@yahoo.com

B. O. Chikere

Health, Safety and Environment (HSE),

Shell Petroleum Development Company,

P.O. Box 263, Port Harcourt, Rivers State, Nigeria
Staphylococcus spp. 3 (5.78\%), Pseudomonas spp. 7 (13.46\%), Citrobacter sp. 1 (1.92\%), Klebsiella sp. 1 (1.92\%), Corynebacterium spp. 5 (9.62\%), Bacillus spp. 5 (9.62\%), Rhodococcus spp. 7 (13.46\%), Alcanivorax spp. 7 (13.46\%), Alcaligenes sp. 1 (1.92\%), Serratia spp. 2 (3.85\%), Arthrobacter spp. 7 (13.46\%), Nocardia spp. 2 (3.85\%), Flavobacterium sp. 1 (1.92\%), Escherichia sp. 1 (1.92\%), Acinetobacter sp. 1 (1.92\%), Proteus sp. 1 (1.92\%) and unidentified bacteria $10(17 \%)$. These results indicate that the marine sediment investigated is amenable to bioreactor-based bioremediation and that abiotic factors also could contribute to hydrocarbon attenuation as recorded in the heat-killed (BAUT) control.

Keywords Niger Delta - Marine sediment - Bioreactor . Crude oil $\cdot$ Bonny loading jetty

\section{Introduction}

Aquatic ecosystems are permanently challenged with hydrocarbons of different composition and origin. During exploration, production, refining, transport and storage of petroleum and petroleum products, some accidental spills could occur (Mnif et al. 2009). The threat of petroleum pollution not only from natural sources such as seeps but also by anthropogenic activities as spillages during transportation, direct discharge from effluent treatment plants and other emissions, endangers the marine biodiversity (Gertler et al. 2009a; Nogales et al. 2011). For instance, in Nigeria, the Niger Delta region produces more than $80 \%$ of the country's crude oil. There is presently an unprecedented increase in the upstream and downstream activities of the oil and allied industries in this oil-rich area (Abu and Chikere 2006; Chikere et al. 2009a, b). Over the years, 
these oil companies have generated myriad of pollutants in the form of gaseous emissions, oil spills, effluents and solid waste (Odeyemi and Ogunseitan 1985; Nweke and Okpokwasili 2004) that have polluted the marine environment beyond sustainability. Heightened navigational activities in inland and coastal waters of the Niger Delta region is another anthropogenic source of refined petroleum pollution of the aquatic environment. An investigation of the polycyclic aromatic hydrocarbons (PAHs) concentrations in some Niger Delta sediments carried out by Ezemonye and Ezemonye (2005) revealed elevated values of these priority pollutants in the sediments studied.

Given the high energy content of highly reduced compounds like petroleum hydrocarbons, it is hardly surprising that many microbes have evolved or acquired the ability to utilize hydrocarbons as sources of carbon and energy (Yakimov et al. 2007; Gertler et al. 2009b). The biodegradation of hydrocarbons is a process well established in nature and known to man for a long time. Mostly limited due to the low mineral nutrient levels in seawater and sediments, biodegradation of hydrocarbons is mediated by numerous genera of marine bacteria (Head and Swannell 1999; Kasai et al. 2002; Head et al. 2006; Paisse et al. 2008). Knowledge of indigenous oil-degrading bacteria and their nutritional requirements have helped scientists to look for ways of employing self-purification/cleaning function of the aquatic ecosystem in order to mitigate marine oil pollution by bioremediation. Bioremediation is the biotechnology which makes use of the catabolic activities of indigenous hydrocarbon utilizing bacteria to decontaminate oil-polluted environments (Mahmoud et al. 2009). Bioremediation can be applied as green technologies as it offers an environmentally friendly and cost effective response to marine oil pollution. Three principal approaches of this technique: natural attenuation (reliance on natural biodegradation activities and rates), which is sometimes called intrinsic bioremediation; biostimulation (stimulation of natural activities by environmental modification such as fertilizer addition to increase rates of biodegradation); and bioaugmentation (addition of exogenous microorganisms to supplant the natural degradative capacity of the hydrocarbon-impacted ecosystem) for in situ biodegradation have been applied several times at pilot and field scale levels with varying degrees of success (Kaplan and Kitts 2004; Prince and Atlas 2005; Chikere et al. 2009a, b; Gertler et al. 2009a).

Based on the different bioremediation approaches mentioned above, several biological methods are employed in the treatment of petroleum impacted environmental media which include bioreactor-based treatment, landfarming, biopiling, composting, bioventing, biosparging, biofiltration and phytoremediation (rhizoremediation) (Young and Cerniglia 1995; Siciliano et al. 2003; Montiel et al. 2009).
Of all these, bioreactor-based treatment has an edge over other methods because it provides an optimal controlled environment for the biodegradation of hydrocarbon-polluted media and eliminates most of the rate-limiting/variable factors such as oxygen supply, optimal $\mathrm{pH}$, temperature and specific nutrient formulations associated with the other methods (Van Hamme et al. 2003). Bioreactors, which can be applied in bioremediation strategies, are basically tanks in which living organisms carry out biological reactions. Their efficiency is based on the ability of bacteria to attach to inert packing, such as granular activated carbon, at interfaces to generate high biomass (Bouwer and McCarty 1982; Teitzel and Parsek 2003). The reactor should also be easy to maintain and operate (Evangelho et al. 2001), and should be able to function under aerobic and anaerobic conditions. Bioreactors can accommodate solids concentrations of $5-50 \% \mathrm{wt} / \mathrm{vol}$. Through break up of solid aggregates and dispersion of insoluble substrates, hydrocarbon desorption and contact with the aqueous phase is promoted, resulting in increased biodegradation. Bioreactor-based petroleum sludge/slurry treatment also allows management of volatile organic compounds (VOCs) by creating reactor conditions which accelerate the process of bioremediation of these VOCs rather than their attenuation via volatilization as obtained in other open treatment methods (Young and Cerniglia 1995).

Various types of bioreactors are widely used in a large variety of aerobic bioprocesses such as aerobic fermentation, biological waste water and hydrocarbon impacted soil/sediments treatments among others (Van Hamme et al. 2003). Stirred tank bioreactors are mechanically agitated where the stirrers are the main gas-dispersing tools and provide high values of mass transfer rates coupled with excellent mixing. Pneumatically agitated bioreactors have two configurations namely bubble columns and airlift bioreactors. In these bioreactors, the low shear environment compared to the stirred tanks is beneficial for successful cultivation of shear sensitive and filamentous cells (Garcia-Ochoa and Gomez 2009).

In the present research, 7 stirred tank bioreactors were used for the bioremediation of marine sediments impacted with petroleum hydrocarbons (crude oil and anthracene). Different nutrient regimens were formulated using organic and inorganic nutrient sources namely NPK fertilizer, urea fertilizer and poultry litter to enhance the biodegradation of the pollutants by the extant autochthonous marine hydrocarbon degrading bacteria. The objectives of the research were to use laboratory bioreactors to investigate the catabolic potential of natural marine microbial communities to biodegrade target hydrocarbon pollutants and also to evaluate the efficacy of biostimulation during hydrocarbon degradation by natural microbial communities augmented with nitrogen and phosphorus additions. 


\section{Materials and methods}

Sampling site/sample collection

The sediments were collected from Bonny River loading jetty, in Bonny Island, Rivers State, Nigeria. Bonny Island is located in the South region of Nigeria and forms heart of the oil-rich Niger Delta. It houses Nigeria's major crude oil export terminal and most of the country's oil installations. This area also experiences heightened navigational activities and as such spills of petroleum hydrocarbons from both crude oil and refined products occur regularly. A section of speed boats and operators seen as at the time the sediments were collected are shown in Fig. 1. Films of petroleum products were seen on the surface of the seawater indicating that this marine ecosystem is constantly exposed to petroleum hydrocarbons. Sediment samples were collected from a depth of $30 \mathrm{~m}$ with Eckman grab (Wild Life Supply Co., NY) with a sterile Thermocool warmer. Seawater was collected with sterile 201 container. All samples were transported to the laboratory within $6 \mathrm{~h}$ for analyses.

\section{Bioslurry bioreactors}

Bioremediation of hydrocarbon-impacted marine sediments from Bonny Island loading jetty was conducted with (7) 2.51 bioslurry bioreactors (Fig. 2) operated over a 56-day period. Two reactors served as controls (unamended [designated BUNa] and heat-killed [designated BAUT]), while the remaining 5 served as nutrientamended bioreactors. Each of the 7 bioreactors received $1 \mathrm{~kg}$ (wet weight) of sediments, 11 of seawater, $20 \mathrm{ml}$ of crude oil and $20 \mathrm{mg}$ of anthracene (Table 1). For the controls, the unamended treatment was only spiked with the hydrocarbons without nutrient addition to determine whether the indigenous bacteria in the sediments have the natural propensity to degrade petroleum hydrocarbons

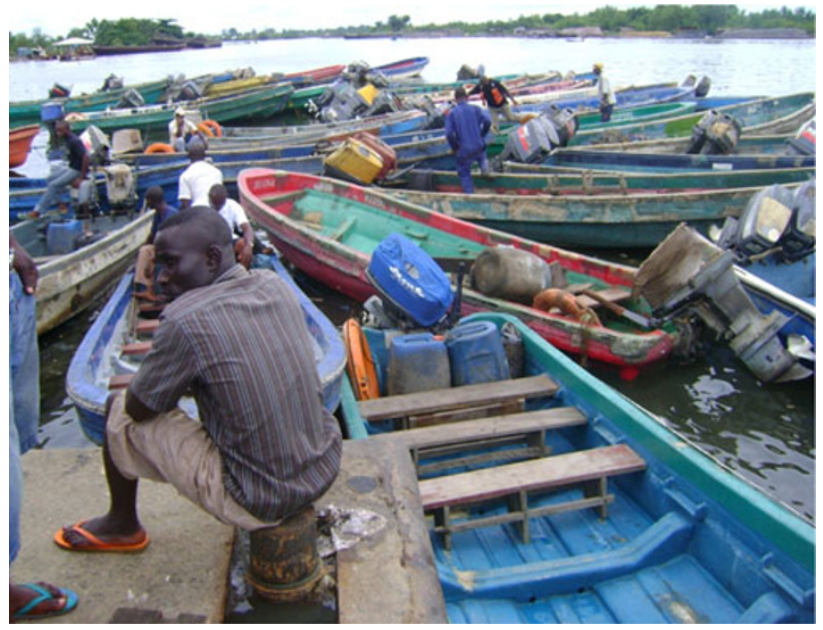

Fig. 1 Speed boats and operators at Bonny Island loading jetty. These speed boats are driven with either premium motor spirit (PMS) or automotive gas oil (AGO), all refined petroleum
Fig. 2 The 7 (2.5 1) bioreactors used in the bioremediation experiment

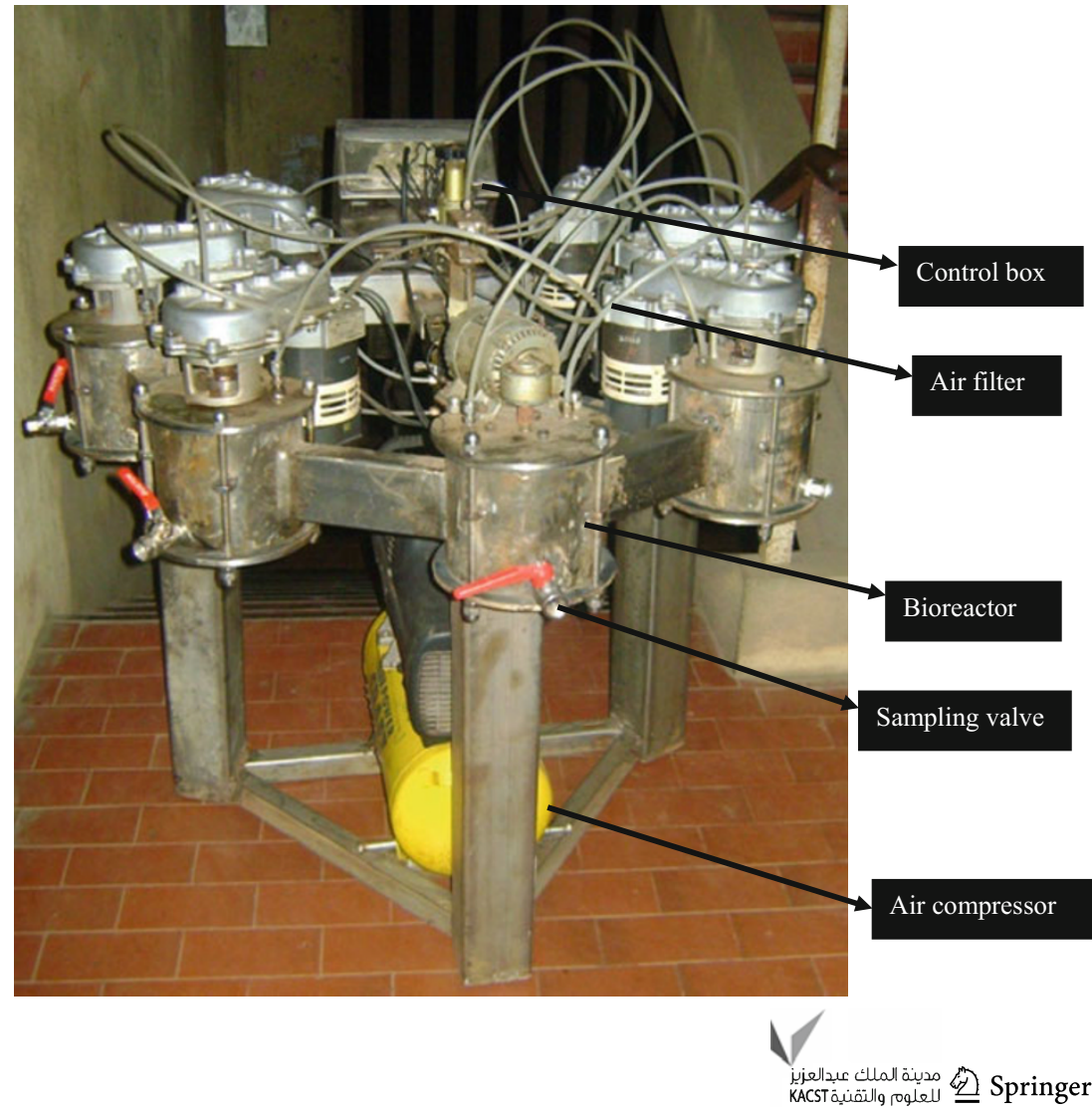


Table 1 Experimental design

\begin{tabular}{|c|c|c|c|}
\hline $\begin{array}{l}\text { Bioreactor } \\
\text { code }\end{array}$ & Test experiment (amended) & $\begin{array}{l}\text { Bioreactor } \\
\text { code }\end{array}$ & Control experiment (unamended) \\
\hline BNK5 & 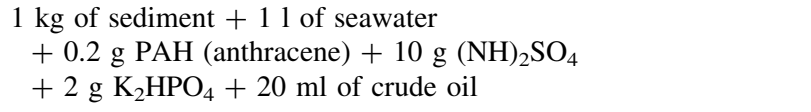 & $\mathrm{BUNa}$ & $\begin{array}{l}1 \mathrm{~kg} \text { of sediment }+11 \text { of seawater } \\
\quad+20 \mathrm{ml} \text { of crude oil } \\
+0.2 \mathrm{~g} \mathrm{PAH} \mathrm{(anthracene)}\end{array}$ \\
\hline BPD & $\begin{array}{l}1 \mathrm{~kg} \text { of sediment }+11 \text { of seawater } \\
\quad+0.2 \mathrm{~g} \mathrm{PAH} \text { (anthracene) }+20 \mathrm{ml} \text { of crude oil } \\
\quad+20 \mathrm{~g} \text { of poultry droppings }+2 \mathrm{~g} \mathrm{~K}_{2} \mathrm{HPO}_{4}\end{array}$ & BAUT & $\begin{array}{l}1 \mathrm{~kg} \text { of heat killed sediment }+11 \text { of } \\
\text { heat killed seawater }+20 \mathrm{ml} \text { of crude } \\
\text { oil }+0.2 \mathrm{~g} \mathrm{PAH} \mathrm{(anthracene)}\end{array}$ \\
\hline BUK & $\begin{array}{l}1 \mathrm{~kg} \text { of sediment }+11 \text { of seawater } \\
\quad+20 \mathrm{ml} \text { of crude oil }+0.2 \mathrm{~g} \text { PAH (anthracene) } \\
\quad+1 \mathrm{~g} \mathrm{~K}_{2} \mathrm{HPO}_{4}+10 \mathrm{~g} \text { of urea }\end{array}$ & & \\
\hline $\mathrm{BNO}_{3}$ & $\begin{array}{l}1 \mathrm{~kg} \text { of sediment }+11 \text { of seawater }+0.2 \mathrm{~g} \text { PAH (anthracene) } \\
\quad+20 \mathrm{ml} \text { of crude oil }+10 \mathrm{~g} \text { of } \mathrm{NH}_{4} \mathrm{NO}_{3}+2 \mathrm{~g} \text { of } \mathrm{K}_{2} \mathrm{HPO}_{4}\end{array}$ & & \\
\hline BNPK & $\begin{array}{l}1 \mathrm{~kg} \text { of sediment }+11 \text { of seawater }+0.2 \mathrm{~g} \text { PAH (anthracene) }+ \\
20 \mathrm{ml} \text { of crude oil }+20 \mathrm{~g} \text { of NPK 20:10:10 }\end{array}$ & & \\
\hline
\end{tabular}

where as the heat-killed treatment (killed by autoclaving sediments and seawater at $121{ }^{\circ} \mathrm{C}$ for $15 \mathrm{~min}$ at $15 \mathrm{psi}$ on 2 consecutive days) was set up to measure the role of abiotic factors in the loss of petroleum hydrocarbons.

The bioreactors were loaded with sediment and hydrocarbons (crude oil and anthracene) and five were amended with nutrients while two served as controls as shown in Table 1 .

The bioreactors were continuously stirred (by 2 impellers) at $150 \mathrm{rpm}$ throughout the 56-day experimental period. The interior of the bioreactors with the accessories are shown in Fig. 3. Filtered air was supplied to the bioreactors from the air compressor through hoses running in and out of them. They were sealed with Teflon to prevent the ingress of atmospheric air and egress of the slurry and were operated at room temperature $\left(28^{\circ} \mathrm{C}\right)$ through out the experimental period. $\mathrm{pH}$ in the 7 bioreactors at day zero ranged from 7.3 to 7.9 after adjustment.

\section{Statistical analysis of data}

Statistical analysis was performed on the data generated from the bacterial counts and hydrocarbon concentrations for the different treatments using one way ANOVA and Tukey's Multiple Comparison Test. The software GraphPad Prism (GraphPad Software, CA, USA) for Windows version 5.01 was used to do the analysis.

Enumeration/identification of total heterotrophic bacteria (THB) and hydrocarbon utilizing bacteria (HUB)

Bacterial counts for THB and HUB were done on days 0, 7, 14, 28 and 56, respectively. From each bioreactor, $1 \mathrm{~g}$ (wet weight) of sediment was homogenized in $0.85 \%$ of normal saline. Decimal dilutions (tenfold) of the suspensions were plated out in duplicate on Plate Count Agar (Merck, Germany) modified with $10 \% \mathrm{NaCl}$ and incubated at $30{ }^{\circ} \mathrm{C}$ for $24 \mathrm{~h}$ for the THB counts. For HUB counts, appropriate dilutions of sediment suspensions from each bioreactor ( $1 \mathrm{~g}$ wet weight of sediment homogenized in $0.85 \%$ of normal saline) were plated out in duplicate on BushnellHaas agar (Sigma-Aldrich, USA) modified with $10 \% \mathrm{NaCl}$. Hydrocarbons were supplied through the vapour phase to putative hydrocarbon utilizers by placing sterile Whatmann No. 1 filter papers impregnated with $5 \mathrm{ml}$ Okono medium crude oil in the lids of the inverted Petri plates. Plates were incubated at $30{ }^{\circ} \mathrm{C}$ for 7 days. Individual colonies of "putative" hydrocarbon utilizers were be picked off the Bushnell-Haas agar plates and subcultured in order to check their ability to utilize hydrocarbons by plating out again on Bushnell-Haas agar (Sigma-Aldrich, USA). Hydrocarbons were supplied to the colonies by the vapour phase transfer using crude oil. The following biochemical tests: oxidase, citrate utilization, catalase, indole production, triple sugar iron utilization, methyl red-Voges Proskauer, glucose fermentation, gelatin liquefaction, urease production were used to identify and characterize the hydrocarbon utilizing bacteria. Other phenotypic tests carried out were Gram stain and motility test. Antibiogram of all the Gram-negative bacilli was determined using the disc diffusion method (Chikere et al. 2008) with the following antibiotics: ampiclox, cotrimoxazole, gentamycin, nalidixic acid, chloramphenicol, nitrofurantoin, streptomycin, tetracycline and erythromycin to aid in the identification of Alcanivorax spp. as adapted from $\mathrm{Wu}$ et al. (2009). The disappearance of TPHs and PAHs was analyzed on each sampling day with GC-FID. The hydrocarbons in the sediment samples for each treatment in the bioreactors were quantified using an Agilent 6890N Network gas chromatograph equipped with flame ionization detector. The carrier gas was helium and the column with 
Fig. 3 Design of the interior of the 2.51 bioreactors used for the bioremediation experiment

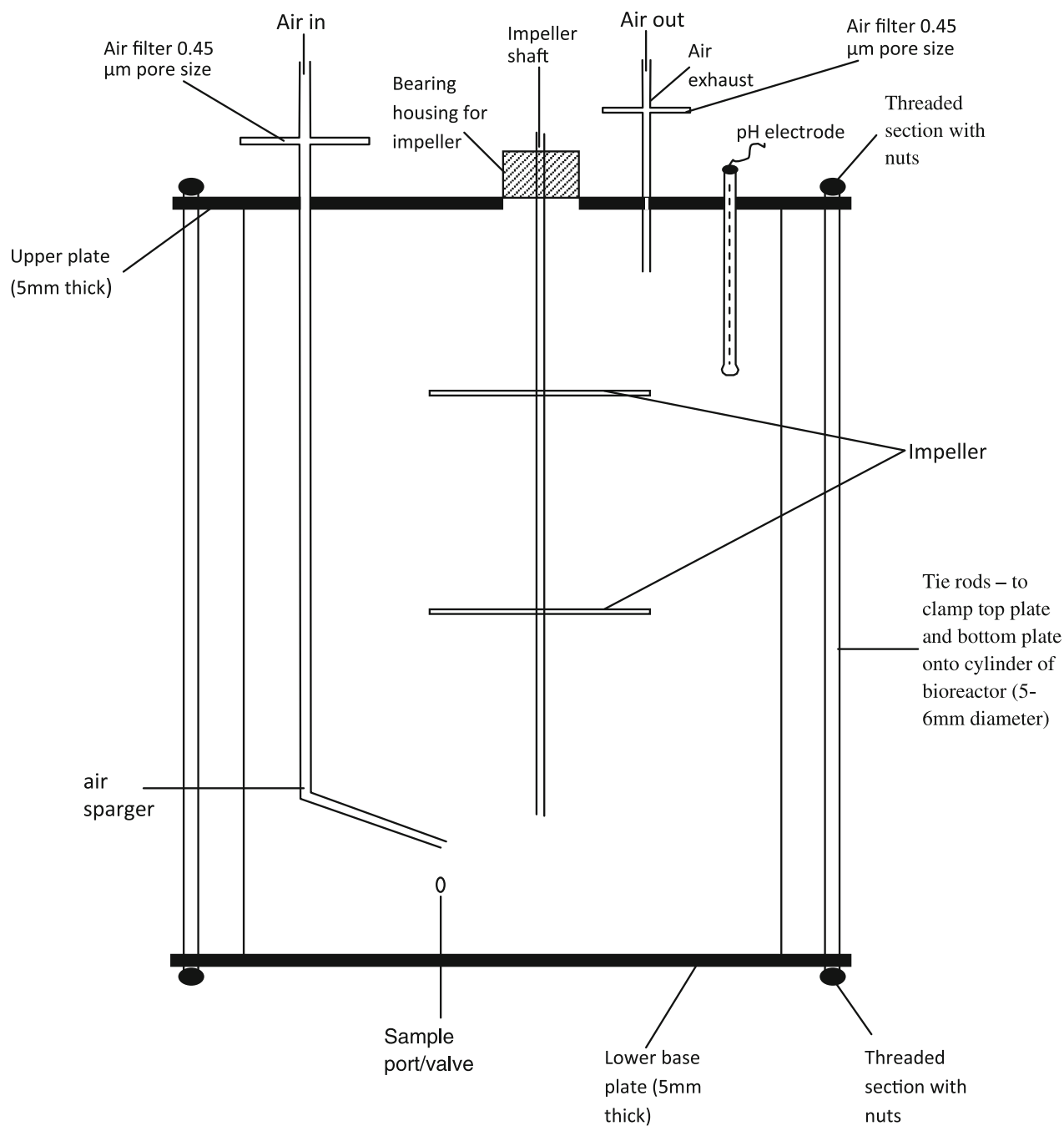

conductivity and total organic carbon contents) and gas chromatographic analysis of total petroleum hydrocarbons (TPH) and polycyclic aromatic hydrocarbons (PAHs) in the sediment sample are presented in Table 2. The bacterial counts (for both total heterotrophic and hydrocarbon utilizing bacteria) were within the same range of $10^{5} \mathrm{cfu} / \mathrm{g}$ which was indicative of the fact that the bacterial community making up the total heterotrophic bacteria were all capable of utilizing petroleum hydrocarbons. This phenomenon occurs when an environment is chronically exposed to hydrocarbons from anthropogenic sources (Rosenberg and Ron 1996; Yakimov et al. 2007; Gertler et al. 2009a, b). The concentrations of the TPH and PAHs in the sediment also showed that there is a metabolically active bacterial community in the sediments that probably uses the hydrocarbons as source of carbon and energy owing to their low concentration in this sediment that is always inundated with petroleum hydrocarbons. The baseline hydrocarbon contents in the sediment prior to bioremediation were $3.34 \mathrm{ppm}$ and $<0.1 \mathrm{ppm}$ TPH and PAHs, respectively. The Okono medium crude oil sample trophic and hydrocarbon utilizing bacteria), physicochemical parameters $(\mathrm{pH}$, nitrate, phosphate, potassium, 
Table 2 Baseline characteristics of sediment sample

\begin{tabular}{ll}
\hline Parameter & Concentration \\
\hline Total heterotrophic bacterial count (THB) & $6.5 \times 10^{5} \mathrm{cfu} / \mathrm{g}$ \\
Hydrocarbon utilizing bacterial count (HUB) & $7.8 \times 10^{5} \mathrm{cfu} / \mathrm{g}$ \\
$\mathrm{pH}$ & 9.84 \\
Conductivity & $1,082 \mu \mathrm{S} / \mathrm{cm}$ \\
Potassium & $18.7 \mathrm{mg} / \mathrm{kg}$ \\
Phosphate & $1.65 \mathrm{mg} / \mathrm{kg}$ \\
Total organic carbon (TOC) & $0.2 \%$ \\
Nitrate & $2.65 \mathrm{mg} / \mathrm{kg}$ \\
Total petroleum hydrocarbons (TPH) & $3.34 \mathrm{ppm}$ \\
Polycyclic aromatic hydrocarbons (PAHs) & $<0.1 \mathrm{ppm}$ \\
\hline
\end{tabular}

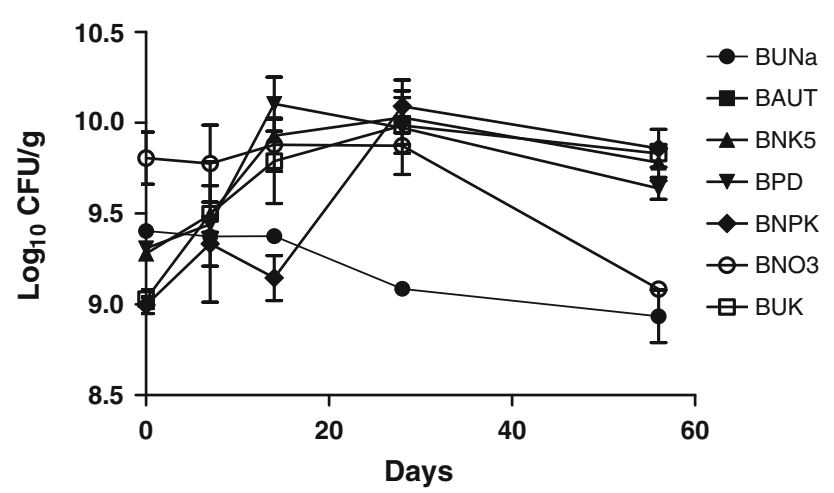

Fig. 4 Total heterotrophic bacterial (THB) counts during the 56-day bioremediation

used in the spiking of the sediment contained 606,863 and $8,748 \mathrm{ppm}$ for both TPH and PAHs, respectively. All other parameters measured showed that there is active microbial activity in the sediment since their concentrations were low.

Bacterial counts and hydrocarbon degradation during bioremediation

During the 56-day bioremediation project, different trends were observed in all the biological and physicochemical parameters analyzed in the different amended and control sediment samples in the bioreactors.

Figure 4 shows the total heterotrophic bacterial counts (THB). There was a general increase for all treatments but $\mathrm{BNO}_{3}$ had the highest count of $7.9 \times 10^{9} \mathrm{cfu} / \mathrm{g}$. All other treatments which were BUNa, BNK5 BPD, BNPK and BUK increased from $10^{8} \mathrm{cfu} / \mathrm{g}$ by day 0 to $10^{9} \mathrm{cfu} / \mathrm{g}$ by day 56 when the experiment ended. BAUT recorded no bacterial growth throughout the experimental period. THB counts were statistically significant at $P<0.05$ using one way ANOVA and Tukey's multiple comparison test.

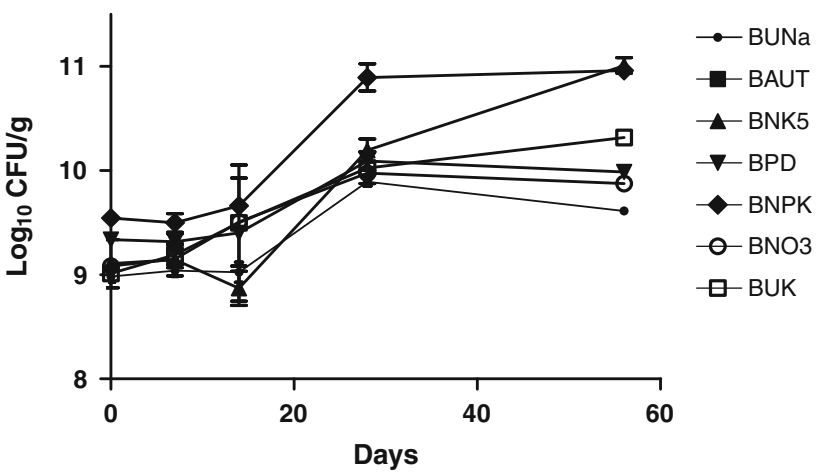

Fig. 5 Hydrocarbon utilizing bacterial (HUB) counts during the 56-day bioremediation

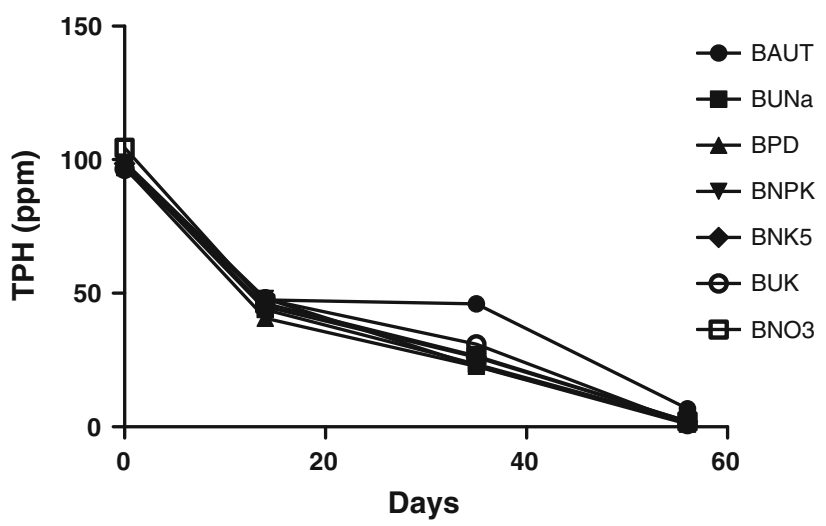

Fig. $6 \mathrm{TPH}$ content in different treatments during the 56-day bioremediation

Figure 5 represents the hydrocarbon utilizing bacterial (HUB) counts across all treatments including controls during the 56-day bioremediation. HUB counts in all treatments $\mathrm{BNO}_{3}, \mathrm{BUNa}, \mathrm{BNK} 5 \mathrm{BPD}, \mathrm{BNPK}$ and BUK increased from $10^{8} \mathrm{cfu} / \mathrm{g}$ by day 0 to $10^{10} \mathrm{cfu} / \mathrm{g}$ by day 56 . BNPK recorded the highest HUB counts throughout the experimental period with a peak of $8.2 \times 10^{10} \mathrm{cfu} / \mathrm{g}$ by day 35. The heat-killed control BAUT showed no growth for THB and HUB throughout the study period. HUB counts were statistically significant at $P<0.05$ using one way ANOVA and Tukey's multiple comparison test.

The degradation of the hydrocarbons (TPHs and PAHs) present in the sediment samples amended with different nutrient sources and the biotic and abiotic controls (BUNa and BAUT) are shown in Figs. 6 and 7. By day 56, the percentages of biodegradation of PAHs, as measured with GC-FID were BNK5 (97.93\%), BNPK (98.38\%), BUK (98.82\%), BUNa (98.13\%), BAUT $(93.08 \%), \quad$ BPD (98.92\%), and $\mathrm{BNO}_{3}(98.02 \%)$. BPD gave the highest level of degradation for PAHs. The extents of degradation of TPH were as follows; BNK5 (94.50\%), BNPK (94.77\%), BUK (94.10\%), BUNa (94.77\%), BAUT (87.13\%), BPD 


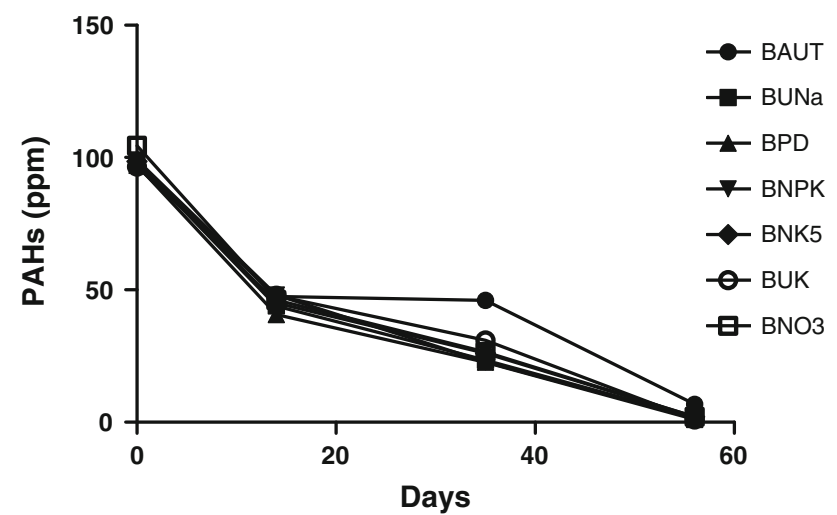

Fig. 7 PAHs content in different treatments during the 56-day bioremediation

(95.35\%), $\mathrm{BNO}_{3}$ (95.54\%). TPH content in all treatments and controls were between 106 and $124.2 \mathrm{ppm}$ by day 0 . By day 56, the TPH content decreased and fell within 4.7 and $15 \mathrm{ppm}$. TPH content across all treatments and controls were not statistically significant at $P<0.05$ using one way ANOVA and Tukey's multiple comparison test. PAHs content in all treatments and controls were between 96 and $104.4 \mathrm{ppm}$ by day 0. By day 56, PAHs content in all nutrient-amended treatments and controls decreased and fell within the range of 1.1 and $6.8 \mathrm{ppm}$. PAHs content across all treatments and controls were not statistically significant at $P<0.05$ using one way ANOVA and Tukey's multiple comparison test.

\section{Characteristics of bacterial isolates}

A variety of bacteria were isolated from the nutrient-amended sediment samples during the 56-day bioremediation project, all of which were from genera of bacteria known to have the ability to degrade petroleum hydrocarbons. These isolates were fifty-nine in number, forty-nine of which were assigned tentative identities and belonged to the genera Micrococcus, Staphylococcus, Pseudomonas, Citrobacter, Klebsiella, Corynebacterium, Bacillus, Rhodococcus, Alcanivorax, Alcaligenes, Serratia, Arthrobacter, Nocardia, Flavobacterium, Escherichia, Acinetobacter, and Proteus. However, Bacillus appeared from the baseline to day 56, with Pseudomonas, Rhodococcus, Alcanivorax, and Corynebacterium being the dominant genera isolated.

Ten bacterial isolates could not be given tentative identities and were designated unidentified bacterial isolates. The diversity of bacterial isolates identified on days 0,14 and 56 of the bioremediation experiment are presented in Tables 3, 4 and 5 while Table 6 shows the frequency of isolation of the bacteria identified in the study.

\section{Discussion and conclusion}

Bioremediation of oil-polluted marine sediments was investigated in seven stirred-tank slurry bioreactors with appropriate amount of nutrient sources such as $\mathrm{K}_{2} \mathrm{HPO}_{4}$, $\mathrm{NH}_{4} \mathrm{NO}_{3}$, $\left(\mathrm{NH}_{4}\right)_{2} \mathrm{SO}_{4}$, NPK, urea or poultry droppings to stimulate extant autochthonous marine bacteria. Physicochemical, total heterotrophic bacterial counts (THB), hydrocarbon utilizing bacterial counts (HUB), as well as gas chromatographic analyses were carried out on the nutrient-amended and control samples over a 56-day period as the experiment progressed. BUNa (unamended control) was composed of the sediment and indigenous bacteria only. The total heterotrophic bacterial (THB) count was $2.53 \times 10^{9} \mathrm{cfu} / \mathrm{g}$ on day 0 and decreased to $9 \times 10^{8} \mathrm{cfu} / \mathrm{g}$ on day 56. From this result, it was clear that the indigenous bacteria in the sediment were already acclimatized to hydrocarbons since there was also loss in TPH and PAHs in this control as bioremediation progressed. Odokuma and Dickson (2003) observed similar results.

The TPHs decreased from an initial 54.99748 to $6.26229 \mathrm{ng} / \mu \mathrm{L}$, while the PAHs reduced from 98.27679 to $1.84442 \mathrm{ng} / \mu \mathrm{L}$ on day 56 with hydrocarbon chain lengths of $\mathrm{C} 8$ and $\mathrm{C} 10$ left for the TPHs. The unamended control (BUNa) contained populations of crude oil-degrading bacteria which increased with time with the concomitant depletion of hydrocarbons proving that indigenous bacterial communities in the hydrocarbon impacted-marine sediments have the natural capacity to degrade TPHs and PAHs since they could use crude oil components as a source of carbon and energy. Statistically, the rate of degradation of both TPH and PAHs in the unamended control and biostimulated treatments was not significant at $P<0.05$ using one way ANOVA and Tukey's multiple comparison test. This observation meant that biodegradation of crude oil hydrocarbons in the amended and control sediment slurries was taking place at similar rates. Similar observation was made by Rosenberg and Ron (1996) when they reviewed some of the case studies of bioremediation projects that took place shortly after the Exxon Valdez colossal oil spill. In one of such, the researchers used Inipol EAP22 oleophilic fertilizer to treat the oil-impacted shorelines. The researchers found out that C18:phytane ratio in the treated plots reduced during the summer of 1989 when the study was done. However, the control plots also showed a similar decrease in the ratio of hydrocarbons used as biodegradation index. Further statistical analysis showed that bioremediation effect was not significant at $P=0.05$. Venosa et al. (1996) made similar observations when they investigated bioremediation of an experimental oil spill on the shoreline of Delaware Bay. They used a randomized block design to study the influence of biostimulation and bioaugmentation on the removal of crude oil 


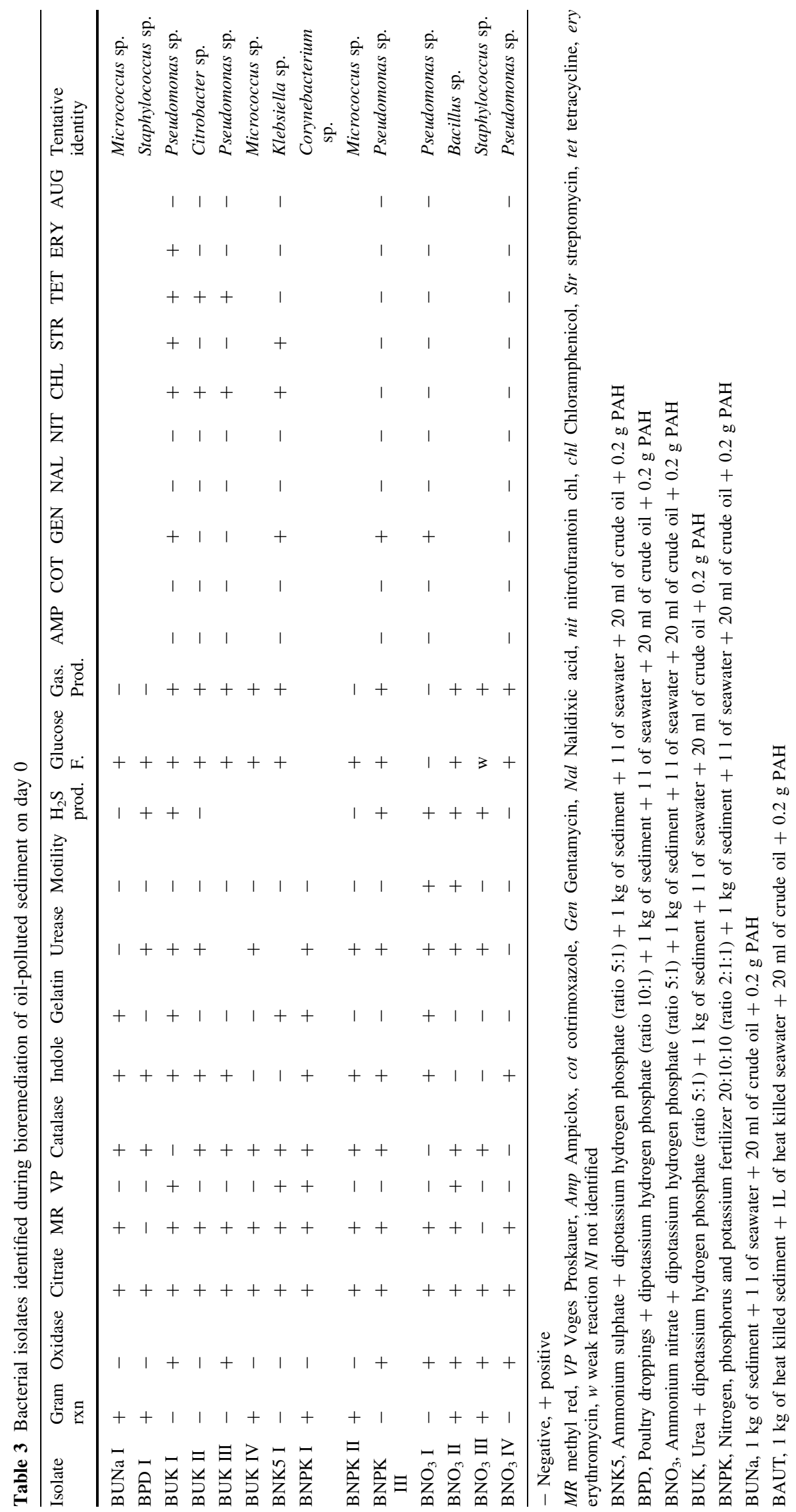




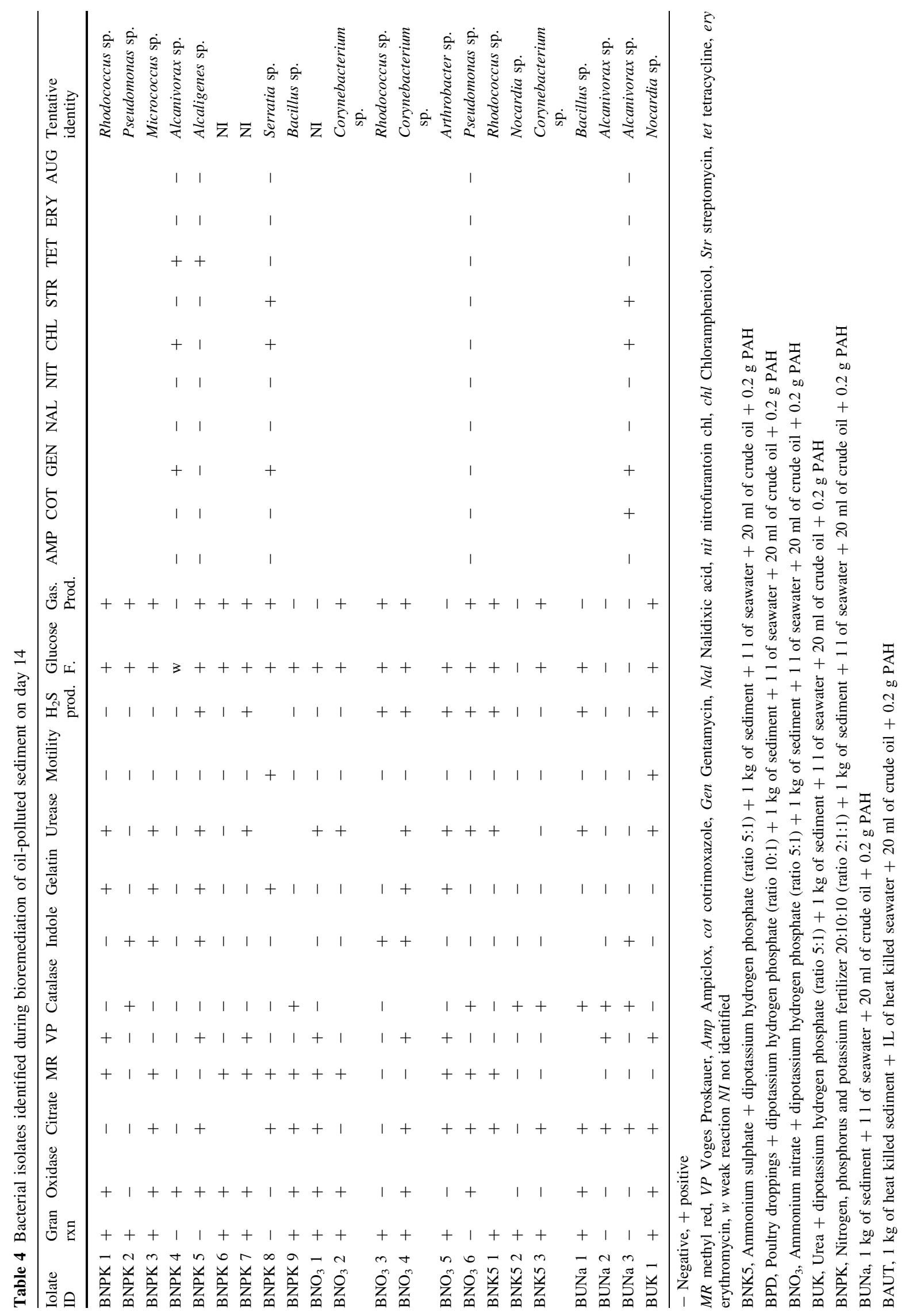




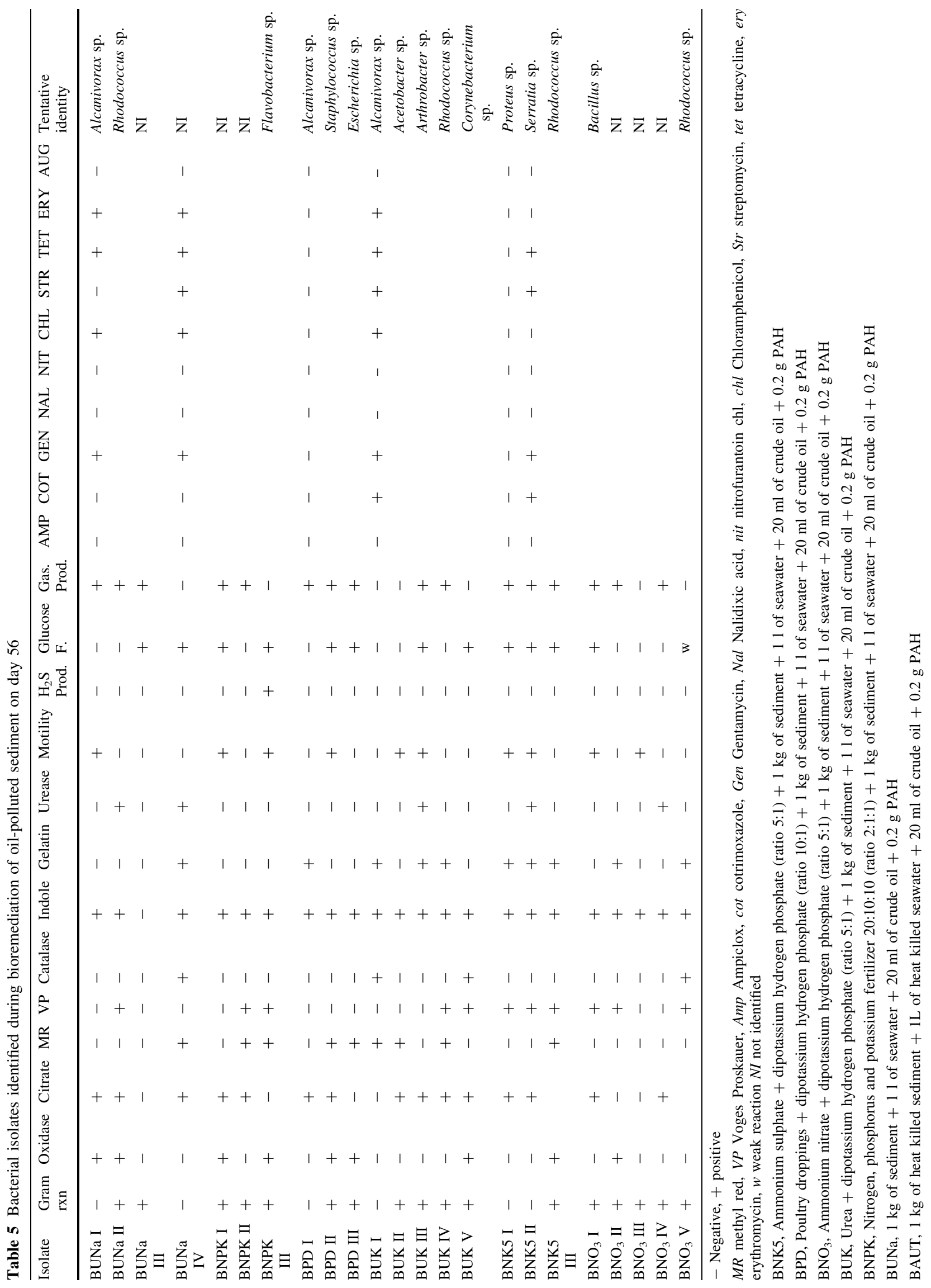


Table 6 Frequency of isolation of different bacteria from sediment

\begin{tabular}{lcc}
\hline Isolate & Frequency & $\begin{array}{c}\text { Percentage } \\
\text { occurrence (\%) }\end{array}$ \\
\hline Micrococcus spp. & 4 & 6.8 \\
Staphylococcus spp. & 3 & 5.1 \\
Pseudomonas spp. & 7 & 11.9 \\
Citrobacter sp. & 1 & 1.7 \\
Klebsiella sp. & 1 & 1.7 \\
Corynebacterium spp. & 5 & 8.5 \\
Bacillus spp. & 4 & 6.8 \\
Rhodococcus spp. & 7 & 11.9 \\
Alcanivorax spp. & 7 & 11.9 \\
Alcaligenes sp. & 1 & 1.7 \\
Serratia spp. & 2 & 3.4 \\
Arthrobacter sp. & 1 & 1.7 \\
Nocardia spp. & 2 & 3.4 \\
Flavobacterium sp. & 1 & 1.7 \\
Escherichia sp. & 1 & 1.7 \\
Acetobacter sp. & 1 & 1.7 \\
Proteus sp. & 1 & 1.7 \\
Unidentified bacteria & 10 & 17.0 \\
\hline
\end{tabular}

in the contaminated sandy beach. High levels of oil biodegradation were seen in the untreated plots, and even though nutrient addition enhanced the rate of biodegradation, they concluded that there was no significant difference between plots treated with nutrients and those that were not. BAUT (heat-killed control) served to measure the effect of abiotic factors on biodegradation since all microbial life was removed by autoclaving the sediment slurry. In this treatment, TPHs reduced from 59.8377 to $14.9339 \mathrm{ng} / \mu \mathrm{L}$, while the PAHs decreased from 98.0682 to $6.785 \mathrm{ng} / \mu \mathrm{L}$ on day 56 . The rate of biodegradation was slightly less than that of the unamended sediment (BUNa) as well as the nutrient-amended sediments. The loss of hydrocarbons can be attributed to abiotic factors since a bioreactor was used and hence no leaching or evaporation of volatile fractions occurred (van Hamme et al. 2003). Invariably microbial activities coupled with abiotic factors (such agitation achieved using the stirrers in the bioreactors) in the sediment could be useful tools for remedial operations. In the amended slurries namely BPD, BUK, BNK5, BNPK and $\mathrm{BNO}_{3}$, it was observed that the THB and HUB counts increased in all five nutrient-enhanced sediments over the 56-day period resulting in corresponding hydrocarbon losses when compared to the heat-killed control that showed no microbial growth. Increases in bacterial counts (for both THB and HUB) in crude oilpolluted soils/sediments amended with organic and inorganic nutrient sources have been reported by other researchers. Roling et al. (2002) examined bacterial dynamics and crude oil degradation after biostimulation and found out that nutrient enhancement increased bacterial counts which correlated significantly with hydrocarbon attenuation. This same observation was made by several workers (Okpokwasili et al. 1986; Okpokwasili and Amanchukwu 1988; Okpokwasili and Odokuma 1994; Okpokwasili and James 1995; Okpokwasili and Ibe 1998; Margesin et al. 2003; Zucchi et al. 2003; Okpokwasili and Ibiene 2006; Okpokwasili and Oton 2006; Ruberto et al. 2006; Quatrini et al. 2008). In the present study, the THB and HUB counts obtained from the nutrient-amended slurries when compared with those from the oil-contaminated-unamended and heat-killed controls were statistically significant at $P<0.05 . \mathrm{BNO}_{3}$ had the highest THB count of $7.9 \times 10^{9} \mathrm{cfu} / \mathrm{g}$, which was closely followed by BPD (poultry litter amended slurry) which had a count of $4.4 \times 10^{9} \mathrm{cfu} / \mathrm{g}$ on day 56 . This increased count in BPD has been attributed to the diverse bacterial populations present in poultry droppings in addition to nutrients contained in it (Williams et al. 1999; Ijah and Antai 2003). This finding is in line with the report of El-Nawawy et al. (1992) that combining oily sludge with the application of inorganic fertilizers gave higher numbers of aerobic bacteria months after application when compared with untreated sediments. Amendment of the crude oil-polluted sediments with the various nutrient regimen stimulated more microbial proliferation in the sediments. The concentration of the crude oil-polluted sediments prior to nutrient enhancement was $3.35 \mathrm{ng} / \mu \mathrm{L}$ for TPHs with $\mathrm{C} 8$ $(0.827 \mathrm{ng} / \mu \mathrm{L}), \mathrm{C} 10(1.3096 \mathrm{ng} / \mu \mathrm{L})$ and C12 (1.21016 ng/ $\mu \mathrm{L})$ chain lengths. The PAHs were naphthalene, fluorene, acenaphthylene, acenaphthene, phenanthrene, anthracene, fluoranthene, pyrene and chrysene with chrysene having the highest peak. The crude oil used in spiking the sediment had a TPH concentration of $6.07 \times 10^{5} \mathrm{ng} / \mu \mathrm{L}$, and PAH a concentration of $8.75 \times 10^{3} \mathrm{ng} / \mu \mathrm{L}$. The PAHs in the crude oil were the same as in the sediment but the TPHs had carbon chain lengths of $\mathrm{C} 8-\mathrm{C} 26$. With $\mathrm{C} 8$ having the highest concentration $\left(1.79 \times 10^{5} \mathrm{ng} / \mu \mathrm{L}\right)$. On day 0 , the TPHs had a total concentration of 113.7922 on average for all treatments with C8-C14 hydrocarbons. The PAHs for all treatments had a concentration of $100.5153 \mathrm{ng} / \mu \mathrm{L}$ on average. On day 56 TPHs decreased appreciably to $5.2237 \mathrm{ng} / \mu \mathrm{L}$ in BPD; $6.3238 \mathrm{ng} / \mu \mathrm{L}$ in BUK; $5.5552 \mathrm{ng} /$ $\mu \mathrm{L}$ in $\mathrm{BNPK} ; 6.2622 \mathrm{ng} / \mu \mathrm{L}$ in $\mathrm{BNK} 5 . \mathrm{BNO}_{3}$ had the highest degradation of $4.74559 \mathrm{ng} / \mu \mathrm{L}$. For the PAHs, BPD showed the highest hydrocarbon loss $(1.05032 \mathrm{ng} / \mu \mathrm{L})$ when compared to the other treatments and the controls.

This may be due to the fact that nutrients were more in abundance in the poultry droppings than in the fertilizer and inorganic sources of nitrogen and phosphorus amended sediments. The hydrocarbon losses recorded in the biostimulated sediments slurries can be attributed to microbial 
activities which resulted in consumption of nitrogen and phosphorus added in the form of urea, NPK fertilizer, poultry droppings, and inorganic sources of nitrogen and phosphorus. Roling et al. (2004) reported that nutrient amendment over a wide range of concentration significantly improved crude oil degradation. The hydrocarbon utilizing bacteria isolated from the active bioreactors were Pseudomonas spp., Serratia sp., Staphylococcus spp., Citrobacter sp., Micrococcus spp., Corynebacterium spp., Bacillus sp., Rhodococcus spp., Klebsiella sp., Flavobacterium sp., Alcanivorax spp., Alcaligenes sp., Nocardia sp., Arthrobacter sp., Escherichia sp., Proteus sp., and Acetobacter $\mathrm{sp}$. However, Bacillus appeared from the baseline to day 56, with Pseudomonas, Rhodococcus, Alcanivorax and Corynebacterium being the dominant genera isolated. The Alcanivorax spp. have been well documented as very important hydrocarbon degraders in marine sediments (Head et al. 2006; Yakimov et al. 2007; Rojo 2009).

These Gram-negative bacteria are peculiar as they cannot use carbohydrates and amino acids as growth substrates hence they are called 'obligate hydrocarbonoclastic bacteria' (OHCB). When grown on $n$-alkanes, however, they produce biosurfactants which have been shown to be glucose lipids. They use hydrocarbons almost exclusively as a carbon source. Recent works have revealed that the OHCB play a significant and global role in the natural cleansing of oilpolluted marine systems (Head et al. 2006; Yakimov et al. 2007; Peng et al. 2008; Alonso-Gutierrez et al. 2009; Gertler et al. 2009a, b; Wu et al. 2009; Qiao and Shao 2010; Ager et al. 2010; Obayori and Salam 2010; Nogales et al. 2011). Studies by Leahy and Colwell (1990) also revealed that the following bacterial genera contain well known species of hydrocarbon degraders in marine sediments; Acinetobacter, Alcaligenes, Arthrobacter, Staphylococcus, Bacillus, Flavobacterium, Nocardia, and Pseudomonas, these bacteria were also isolated in this research project. Members of the Enterobacteriaceae family, e.g. Klebsiella, Proteus, Serratia, Escherichia isolated in this research corroborate the report of Prince (2005) which demonstrated them as hydrocarbon utilizers. Kasai et al. (2002) isolated Flavobacterium spp. from oil-polluted marine sediments capable of degrading aromatic hydrocarbons in crude oil. Said et al. (2008) isolated Bacillus, Staphylococcus, Pseudomonas and Acinetobacter spp. capable of degrading PAHs from polluted sediments. The study revealed that biostimulation of crude oil-impacted marine sediments with organic/inorganic sources of nitrogen and phosphorus encourages the proliferation of hydrocarbon utilizing bacteria. Bioremediation technique for removing petroleum hydrocarbons in sediments have been developed around strategies for delivering nutrients and altering the abiotic factors to optimize microbial activity and degradation of pollutants (Ayotamuno et al. 2006; Stroud et al. 2007). Bioremediation has long been applied as a remedial technology that is cost effective, ecologically friendly and efficient for the decontamination of crude oil-polluted sediments and soils (Kaplan and Kitts 2004; Nweke and Okpokwasili 2004; Quatrini et al. 2008). In this investigation, bioreactor-based treatment and amendment of crude oil-polluted sediments with poultry droppings, NPK and urea fertilizers, and inorganic sources of nitrogen and phosphorus caused more proliferation of crude oildegrading bacteria and enhanced microbial degradation of crude oil in the sediment. A combination of $\mathrm{NH}_{4} \mathrm{NO}_{3}$, $\mathrm{K}_{2} \mathrm{HPO}_{4}$, and poultry droppings better enhanced hydrocarbon degradation than did the fertilizers urea and NPK alone. It was also observed that the unamended sediment which served as a natural attenuation control recorded appreciable hydrocarbon degradation. There was hydrocarbon loss in the heat-killed control signifying that abiotic factors could as well contribute to hydrocarbon attenuation in the environment. These results indicate that the marine sediment investigated is amenable to bioreactor-based bioremediation and that the extant autochthonous bacteria in the hydrocarbon-impacted Niger Delta sediments have the natural propensity to utilize hydrocarbons. Therefore, for effective bioremediation of petroleum hydrocarbon-impacted sediments, nitrogenous fertilizer (NPK and urea), poultry droppings and inorganic sources of nitrogen and phosphorus could be used. Further studies also need to be carried out in order to study in details the genetics of the hydrocarbon degrading bacteria in this Niger Delta marine sediments to ascertain the degradative genes/enzymes they posses.

Acknowledgments This research was supported by a Grant (W/ 4263-1F) given to the corresponding author from the International Foundation for Science (IFS) Stockholm, Sweden

Open Access This article is distributed under the terms of the Creative Commons Attribution License which permits any use, distribution and reproduction in any medium, provided the original author(s) and source are credited.

\section{References}

Abu GO, Chikere BO (2006) Cell surface properties of hydrocarbonutilizing bacterial isolates from Port Harcourt marine environment. Niger J Microbiol 20:809-816

Ager D, Evans S, Li H, Lilley AK, van der Gast CJ (2010) Anthropogenic disturbance affects the structure of bacterial communities. Environ Microbiol 12:670-678

Alonso-Gutierrez J, Figueras A, Albaigés J, Jimenez N, Vinas M, Solanas AM, Novoa B et al (2009) Bacterial communities from shoreline environments (costa da morte, northwestern Spain) affected by the prestige oil spill. Appl Environ Microbiol 75:3407-3418

Ayotamuno MJ, Kogbara RB, Ogaji SOT, Pobert SD (2006) Bioremediation of a crude oil polluted agricultural soil at Port Harcourt Nigeria. Appl Energy 83:1249-1257 
Bouwer EJ, McCarty PL (1982) Removal of trace chlorinated organic compounds by activated carbon and fixed-film bacteria. Environ Sci Technol 16:836-843

Chikere CB, Chikere BO, Omoni VT (2008) Antibiogram of clinical isolates from a hospital in Nigeria. Afr $\mathrm{J}$ Biotechnol $7: 4359-4363$

Chikere CB, Okpokwasili GC, Chikere BO (2009a) Bacterial diversity in a tropical crude oil-polluted soil undergoing bioremediation. Afr J Biotechnol 8:2535-2540

Chikere CB, Okpokwasili GC, Ichiakor O (2009b) Characterization of hydrocarbon utilizing bacteria in tropical marine sediments. Afr J Biotechnol 8:2541-2544

El-Nawawy AS, El-Bagouri IH, Abdal M, Khalafawi MS (1992) Biodegradation of oily sludge in Kuwait soil. World J Microbiol Biotechnol 8:618-620

Evangelho MR, Gonçalves MMM, Sant'Anna GL Jr, Villas Boas RC (2001) A trickling filter application for the treatment of a gold milling effluent. Int J Miner Process 62:279-292

Ezemonye LIN, Ezemonye NN (2005) Polycyclic aromatic hydrocarbons in surface water and sediments of Niger Delta rivers of Nigeria. J Niger Environ Soc 2:348-358

Garcia-Ochoa F, Gomez E (2009) Bioreactor scale-up and oxygen transfer rate in microbial processes: an overview. Biotechnol Advan 27:153-176

Gertler C, Gerdts G, Timmis KN, Yakimov MM, Golyshin PN (2009a) Populations of heavy fuel oil-degrading marine microbial community in presence of oil sorbent materials. J Appl Microbiol 107:590-605

Gertler C, Gerdts G, Timmis KN, Golyshin PN (2009b) Microbial consortia in mesocosm bioremediation trial using oil sorbents, slow release fertilizer and bioaugmentation. FEMS Microbiol Ecol 69:288-300

Head IM, Swannell RPJ (1999) Bioremediation of petroleum hydrocarbon contaminants in marine habitats. Curr Opin Biotechnol 10:234-239

Head IM, Jones DM, Roling WFM (2006) Marine microorganisms make a meal of oil. Nat Rev Microbiol 4:173-182

Ijah UJJ, Antai SP (2003) The potential use of chicken-drop microorganisms for oil spill remediation. Environmentalist 23:89-95

Kaplan CW, Kitts CL (2004) Bacterial succession in a petroleum land treatment unit. Appl Environ Microbiol 70:1777-1786

Kasai Y, Kishira H, Harayama S (2002) Bacteria belonging to the genus Cycloclasticus play a primary role in the degradation of aromatic hydrocarbons released in a marine environment. Appl Environ Microbiol 68:5625-5633

Leahy JG, Colwell RR (1990) Microbial degradation of hydrocarbons in the environment. Microbiol Rev 54:305-315

Mahmoud HM, Al-Hasan RH, Sorkhoh NA, Eliyas M, Radwan SS (2009) Attenuation of oil pollutants in the Arabian Gulf water by bacteria naturally associated with live fish. Int Biodeterio Biodeg 63:615-620

Margesin R, Labbe D, Schinner F, Greer CW, Whyte LG (2003) Characterization of hydrocarbon degrading microbial populations in contaminated and pristine Alpine soils. Appl Environ Microbiol 69:3085-3092

Mnif S, Chamkha M, Sayadi S (2009) Isolation and characterization of Halomonas sp. Strain C2SS100, a hydrocarbon degrading bacterium under hypersaline conditions. J Appl Microbiol 107:785-794

Montiel C, Quintero R, Aburto J (2009) Petroleum biotechnology: technology trends for the future. Afr J Biotech 8:26532666

Nogales B, Lanfranconi M, Pina-Villalonga JM, Bosch R (2011) Anthropogenic perturbations in marine microbial communities. FEMS Microbiol Rev 35:275-298
Nweke CO, Okpokwasili GC (2004) Effects of bioremediation treatments on the bacterial populations of soil at different depths. Niger J Microbiol 18:363-372

Obayori SO, Salam LB (2010) Degradation of polycyclic aromatic hydrocarbons: role of plasmids. Sci Res Essays 5:4093-4106

Odeyemi O, Ogunseitan OA (1985) Petroleum industry and its pollution potential in Nigeria. Oil Petrochem Pollut 2:223-229

Odokuma LO, Dickson AA (2003) Bioremediation of a crude oilpolluted tropical rain forest soil. Glob J Environ Sci 2:29-40

Okpokwasili GC, Amanchukwu SC (1988) Petroleum hydrocarbon degradation by Candida species. Environ Int 14:243-247

Okpokwasili GC, Ibe SN (1998) Genetically engineered microbes and oil degradation. In: Proceedings of International seminar on petroleum industry and the Nigerian environment. Nigerian National Petroleum Corporation (NNPC), Lagos, pp 97-103

Okpokwasili GC, Ibiene AA (2006) Enhancement of recovery of residual oil using a biosurfactant slug. Afr J Biotech 5:453-456

Okpokwasili GC, James WA (1995) Microbial contamination of kerosene, gasoline, and crude oil and their spoilage potentials. Material und Organismen 29:147-156

Okpokwasili GC, Odokuma LO (1994) Tolerance of Nitrobacter to toxicity of some Nigerian crude oils. Bull Environ Contam Toxicol 52:388-395

Okpokwasili GC, Oton NS (2006) Comparative applications of bioreactor and shake-flask systems in the laboratory treatment of oily sludge. Int J Waste Manag 1:49-60

Okpokwasili GC, Somerville CC, Sullivan M, Grimes DJ, Colwell RR (1986) Plasmid mediated degradation of hydrocarbons in estuarine bacteria. Oil Chem Pollu 5:117-129

Paisse S, Coulon F, Goni-Urriza M, Peperzak L, McGenity TJ, Durand R (2008) Structure of bacterial communities along a hydrocarbon contamination gradient in a coastal sediment. FEMS Microbiol Ecol 66:295-305

Peng R, Xiong A, Sue Y, Fu X, Gao F, Zhao W, Tian Y, Yao Q (2008) Microbial biodegradation of polyaromatic hydrocarbons. FEMS Microbiol Rev 32:927-955

Prince RC (2005) The microbiology of marine oil spill bioremediation. In: Ollivier B, Magot B (eds) Petroleum microbiology. American Society for Microbiology (ASM) Press, Washington DC, pp 317-335

Prince R, Atlas RM (2005) Bioremediation of marine oil spills. In: Atlas RM, Philp J (eds) Bioremediation: applied microbial solutions for real-world environmental cleanup. American Society for Microbiology (ASM) Press, Washington DC, pp 269-292

Qiao N, Shao Z (2010) Isolation and characterization of a novel biosurfactant produced by hydrocarbon degrading bacterium Alcanivorax dieselolei B-5. J Appl Microbiol 108:1207-1216

Quatrini P, Scaglione G, De Pasquale C, Reila S, Puglia AM (2008) Isolation of Gram-positive $n$-alkane degraders from a hydrocarbon contaminated Mediterranean shoreline. J Appl Microbiol 104:251-259

Rojo F (2009) Degradation of alkanes by bacteria. Environ Microbiol 11:2477-2490

Roling WFM, Milner MG, Jone DM, Lee K, Daniel F, Swannell RPJ, Head IM (2002) Robust hydrocarbon degradation and dynamics of bacterial communities during nutrient-enhanced oil spill bioremediation. Appl Environ Microbiol 68:5537-5548

Roling WFM, Milner MG, Jones DM, Fratepietro F, Swannell RPJ, Daniel F, Head IM (2004) Bacterial community dynamics and hydrocarbon degradation during a field scale evaluation of bioremediation in a mudflat beach contaminated with buried oil. Appl Environ Microbiol 70:2603-2613

Rosenberg E, Ron EZ (1996) Bioremediation of petroleum contamination. In: Crawford RL, Crawford DL (eds) Bioremediation: principles and application. Cambridge University Press, Cambridge, pp 100-124

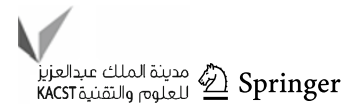


Ruberto L, Dias R, Balbo AL, Vazquez SC, Hernandez EA, Cormack WPM (2006) Influence of nutrients addition and bioaugmentation on the hydrocarbon biodegradation of a chronically contaminated Antarctic soil. J Appl Microbiol 106:1101-1110

Said BO, Goni-Urriza MS, El Bour M, Dellali M, Aissa P, Duran R (2008) Characterization of aerobic polycyclic aromatic hydrocarbon-degrading bacteria from Bizerte lagoon sediments Tunisia. J Appl Microbiol 107:987-997

Siciliano SD, Germida JJ, Banks K, Greer CW (2003) Changes in microbial community composition and function during a polyaromatic hydrocarbon phytoremediation field trial. Appl Environ Microbiol 69:483-489

Stroud JL, Paton GI, Semple KT (2007) Microbe-aliphatic hydrocarbon interactions in soil; implications for biodegradation and bioremediation. J Appl Microbiol 102:1239-1253

Teitzel GM, Parsek MR (2003) Heavy metal resistance of biofilm and planktonic Pseudomonas aeruginosa. Appl Environ Microbiol 69:2313-2320

van Hamme JD, Singh A, Ward OP (2003) Recent advances in petroleum microbiology. Microbiol Molec Biol Rev 67:503-549

Venosa AD, Suidan MT, Wrenn BA, Strohmeier KL, Haines JR, Eberhart BL, King D, Holder E (1996) Bioremediation of an experimental oil spill on the shoreline of Delaware Bay. Environ Sci Technol 30:1764-1775

Williams CM, Grimes JL, Mikkelsen RL (1999) The use of poultry litter as co-substrate and source of inorganic nutrients and microorganisms for the ex-situ biodegradation of petroleum compounds. Poult Sci 78:956-964

Wu Y, Lai Q, Zhongewn Z, Qiao N, Liu C, Shao Z (2009) Alcanivorax hongdengensis sp nov., an alkane-degrading bacterium isolated from surface sea water of the straits of Malacca and Singapore, producing a lipopeptide as its biosurfactant. Int J Syst Evol Microbiol 59:1474-1479

Yakimov MM, Timmis KN, Golyshin PN (2007) Obligate oildegrading marine bacteria. Curr Opin Biotechnol 18:257-266

Young LY, Cerniglia CE (1995) Microbial transformation and degradation of toxic organic chemicals. Wiley, New York, pp 77-125

Zucchi N, Angiolini L, Borin S, Brusetti L, Dietrich N, Gigliotti C, Barbieri P, Sorlini C, Daffonchio D (2003) Response of bacterial community during bioremediation of an oil polluted soil. J Appl Microbiol 94:248-257 